Int. J. Electrochem. Sci., 14 (2019) $8931-8938$

Short Communication

\title{
Highly Proton-conducting Hybrid Materials containing Keggin- type Tungstovanadophosphoric Acids and Organic Polymers
}

\author{
Wenshuang Dai ${ }^{1}$, Xia Tong ${ }^{2}$, Qingyin $W u^{1,2, *}$ \\ ${ }^{1}$ School of Biomedical and Chemical Engineering, Liaoning Institute of Science and Technology, \\ Benxi 117004, Liaoning, P. R. China \\ ${ }^{2}$ Department of Chemistry, Zhejiang University, Hangzhou, 310027, P. R. China \\ *E-mail: qywu@zju.edu.cn
}

doi: $10.20964 / 2019.09 .45$

Received: 3 May 2019 / Accepted: 2 July 2019 / Published: 31 July 2019

Four new proton-conducting hybrid materials were prepared by Keggin-type tungstovanadophosphoric heteropoly acids $\mathrm{H}_{4} \mathrm{PW}_{11} \mathrm{VO}_{40} \cdot \mathrm{nH}_{2} \mathrm{O}\left(\mathrm{PW}_{11} \mathrm{~V}\right)$ and $\mathrm{H}_{6} \mathrm{PW}_{9} \mathrm{~V}_{3} \mathrm{O}_{40} \cdot \mathrm{nH}_{2} \mathrm{O}\left(\mathrm{PW}_{9} \mathrm{~V}_{3}\right)$, organic polymers (polyvinylpyrrolidone, PVP or polyethylene glycol, PEG) and silica gel $\left(\mathrm{SiO}_{2}\right)$ at weight ratio of 80:10:10. Structural analysis reveals that the Keggin anions maintained in the hybrid materials, and these products exhibit high proton conductivity with $1.36 \times 10^{-3}\left(\mathrm{PVP} / \mathrm{PW}_{11} \mathrm{~V} / \mathrm{SiO}_{2}\right), 3.44 \times 10^{-3}$ $\left(\mathrm{PEG} / \mathrm{PW}{ }_{11} \mathrm{~V} / \mathrm{SiO}_{2}\right), 8.90 \times 10^{-3}\left(\mathrm{PVP} / \mathrm{PW}_{9} \mathrm{~V}_{3} / \mathrm{SiO}_{2}\right)$ and $1.63 \times 10^{-2} \mathrm{~S} \cdot \mathrm{cm}^{-1}\left(\mathrm{PEG} / \mathrm{PW}_{9} \mathrm{~V}_{3} / \mathrm{SiO}_{2}\right)$ at $26{ }^{\circ} \mathrm{C}$ and $75 \%$ relative humidity, increasing with higher temperature. Their activation energy of proton conduction is $17.96,15.34,17.54,14.23 \mathrm{~kJ} \cdot \mathrm{mol}^{-1}$, respectively, which is lower than the corresponding pure acid. The proton conduction mechanisms of these materials are also proposed.

Keywords: Keggin structure; heteropoly acids; proton conductivity; hybrid materials; polyoxometalates.

\section{FULL TEXT}

(C) 2019 The Authors. Published by ESG (www.electrochemsci.org). This article is an open access article distributed under the terms and conditions of the Creative Commons Attribution license (http://creativecommons.org/licenses/by/4.0/). 